\title{
The Evaluation of Family Physicians' Knowledge on the Use of Inhalation Devices
}

\author{
ElifTanrverdi ${ }^{1}$, Kezban Özmen Süner², Hasan Süner ${ }^{3}$, Sinem İliaz ${ }^{1}$, Ali Nihat Annakkaya ${ }^{4}$
}

\author{
${ }^{1}$ Clinic of Chest Diseases, Yedikule Chest Diseases and Thoracic Surgery Training and Research Hospital, İstanbul \\ ${ }^{2}$ Department of Anesthesiology and Reanimation, Hacettepe University Faculty of Medicine, Ankara \\ ${ }^{3}$ Clinic of Chest Diseases, Yenimahalle State Hospital, Ankara \\ ${ }^{4}$ Department of Chest Diseases, Düzce University Faculty of Medicine, Düzce
}

\begin{abstract}
Objective: Nowadays, inhalation techniques have an important role in treatment of asthma and chronic obstructive pulmonary disease (COPD). Correct application of inhalation devices is important for optimal therapeutic efficacy. Showing inhalation techniques to patients receiving inhaler therapy in more than one visit reduce the device usage errors. It is important to observe the deficiencies and errors of the patients in the primary health care where the patients frequently admitted. In our study we aimed to evaluate the knowledge of family physians on inhaler device usage in their clinical practice.

Methods: Family physicians who work in primary health care services were visited face to face. Fifty family physicians who were in the institution at visit day and agreed to participate in the study were included in the study. The questionnaire consisting of 15 questions were asked each family physician. Then, seven different inhalation devices were evaluated with 10 step scoring system of inhaler device usage.

Results: Twenty eight (56\%) physicians were female and $22(44 \%)$ were male. The mean age was $36.3 \pm 6.7$ years and mean working time as a family physician was $5.12 \pm 2.8$ years. Nineteen physicians participated to a meeting about usage of inhaler devices in the past. Average scores for inhaler devices were found $7.96 \pm 2.91$ for metered-dose inhaler, $7.54 \pm 3.93$ for discus, $7.28 \pm 4.04$ for handihaler, $6.38 \pm 4.4$ for aerolizer, $6.12 \pm 4.22$ for turbuhaler, $5.98 \pm 4$ for easyhaler and $5.72 \pm 4.59$ for sanohaler, respectively. There was no relation between the inhaler devices usage scores and sex, age, duration of being family physician ( $p>0.05)$. The average scores of physicians who participated to a training were better than the physicians who didn't participate for metered-dose inhalers, turbuhaler, aerolizer and handihaler $(p=0.049, p=0.05, p=0.013$ and $\mathrm{p}=0.021$, respectively).
\end{abstract}

Conclusion: We thought that training of family physicians for inhaler devices is necessary to improve patients' compliance and successful treatment.

Keywords: Asthma, COPD, inhalation administration, primary care physicians

Received Date: 15.01.2015 Accepted Date: 30.04 .2015

Available Online Date: 04.06 .2015

Address for correspondence

Sinem Iliaz

E-mail: snmkaraosman@gmail.com

(7) This work is licensed under a Creative Commons Attribution-NonCommercia 4.0 International License.

DOI: $10.5152 /$ ejp.2015.66375

-Available online at www.eurasianjpulmonol.com

\section{INTRODUCTION}

Inhalation of drug plays an important role in the management of asthma and chronic obstructive pulmonary diseases (COPD). Therapeutic drug directly reaches the lungs through inhalation therapy. Thus, compared to systemic treatment, inhalation therapy provides more rapid and more efficient treatment at lower doses and causes less systemic side-effects (1). Despite this, asthma and COPD attacks can occur in many patients, and a complete control cannot be obtained. Some of the important reasons for this situation are inconsistencies and errors in the usage of inhalers (2-4). Various usage techniques are available for inhalation treatment and new devices are continuously developed. In the studies evaluating whether different inhaler devices are used properly by patients, the rates of correct usage was found to be low $(5,6)$. Hacievliyagil et al. (7) conducted a study with patients who had previously used metered-dose inhaler (MDI), turbuhaler, and discus devices; they found that patients could not effectively use these three devices. None of the three inhaler devices were observed to be superior in terms of treatment. This shows that the correct usage of inhaler device is more efficient than the type of the device in treatment. The most effective way of preventing incorrect usage is to provide adequate education on how to use the inhaler devices. Moreover, controlling the patients' usage of inhaler devices at certain intervals will reduce the rate of incorrect usage. Asthma and COPD, which are important in public health because of their high morbidity and mortality rates, are also frequently encountered by family physicians in their daily practices (8). Therefore, family physicians in primary health care facilities where asthma and COPD patients visit frequently are allocated significant responsibilities. This study was planned for evaluating the knowledge of family physicians on the usage of inhaler devices and for creating awareness on the issue during evaluation. 


\section{METHODS}

Family physicians working in primary health care services were visited face-to-face at their places of work. Of 93 family physicians in the province of Düzce, 50 (53.76\%) physicians who were available at their facilities on the day of visit and who accepted to participate in the study were included in the study. For each family physician, a questionnaire form was completed at the beginning. The questionnaire consisted of questions related to age, gender, and the duration of working as a family physician. Moreover, they were asked about the names of inhaler devices that they knew and whether they prescribed inhaler devices to their patients; if the answer was a yes, then they were further questioned as which methods they used,and if the answer was a no, then they were asked as why they did not prescribe the inhaler device. Then, the usage techniques of seven different inhalation devices were evaluated in 10 steps over 10 points. The inhaler devices, the uses of which were evaluated, were MDI (GlaxoSmithKline, Brendford, England), discus (GlaxoSmithKline, Brendford, England), turbuhaler (Astrazenaca, London, England), aerolizer (Novartis, Basel, Switzerland), easyhaler (Abdi İbrahim, İstanbul, Turkey), handihaler (Pfizer, New York, USA), sanohaler (Sanovel, İstanbul, Turkey). The steps used for each inhalation are presented in Table 1. Each correct step was scored as one point and each incorrect or non-applied step was scored as zero. Total scores were accepted as the skill score. Written informed consent was obtained from all participants. The approval for the study was obtained from the Ethics Committee of the Düzce University Faculty of Medicine (Decision No: 2013/365).

\section{Statistical Analysis}

The skill scores of the family physicians were calculated as mean value \pm standard deviation for each device. For statistical analyses, the

Table 1. The steps in the usage of inhaler devices

\begin{tabular}{|c|c|c|c|c|c|c|}
\hline MDI & Turbuhaler & iscus & Aerolizer & Handihaler & Sanohaler & Easyhaler \\
\hline $\begin{array}{l}\text { 1. Remove cap } \\
\text { 2. Shake inhaler } \\
\text { 3. Hold inhaler } \\
\text { in upright } \\
\text { position } \\
\text { 4. Keep your head } \\
\text { up } \\
\text { 5. Breathe out } \\
\text { 6. Put the } \\
\text { mouthpiece } \\
\text { between your } \\
\text { lips } \\
\text { 7. At the start of } \\
\text { inspiration, } \\
\text { slowly press } \\
\text { canister down } \\
\text { 8. Continue to } \\
\text { inhale deeply } \\
\text { 9. Hold breath for } \\
10 \mathrm{~s} \\
\text { 10.Breathe out } \\
\text { slowly and } \\
\text { completely and } \\
\text { wait for } 20-30 \\
\text { min before } \\
\text { repeating the } \\
\text { steps }\end{array}$ & $\begin{array}{l}\text { 1. Remove cap by } \\
\text { unscrewing } \\
\text { 2. Hold the device } \\
\text { upright } \\
\text { 3. Twist the grip } \\
\text { below the } \\
\text { device forwards } \\
\text { and backwards } \\
\text { until a click is } \\
\text { heard } \\
\text { 4. Keep your head } \\
\text { up } \\
\text { 5. Breathe out } \\
\text { 6. Put } \\
\text { mouthpiece } \\
\text { between your } \\
\text { lips } \\
\text { 7. Breathe in as } \\
\text { deeply and } \\
\text { strongly as } \\
\text { possible } \\
\text { 8. Hold breath for } \\
\text { 10 s } \\
\text { 9. Breathe out } \\
\text { completely } \\
\text { 10. Replace the } \\
\text { cover and if } \\
\text { needed, wait } \\
\text { for } 20 \text { - } 30 \mathrm{~s} \text { for } \\
\text { the second } \\
\text { application }\end{array}$ & $\begin{array}{l}\text { 1. Remove cap by } \\
\text { unscrewing } \\
\text { 2. Push the clip } \\
\text { until a click is } \\
\text { heard } \\
\text { 3. Breathe out } \\
\text { 4. Keep your head } \\
\text { up } \\
\text { 5. Put } \\
\text { mouthpiece } \\
\text { between your } \\
\text { lips } \\
\text { 6. Breathe in as } \\
\text { deeply and } \\
\text { strongly as } \\
\text { possible } \\
\text { 7. Remove inhaler } \\
\text { from your } \\
\text { mouth without } \\
\text { breathing out } \\
\text { 8. Hold breath for } \\
10 \mathrm{~s} \\
\text { 9. Breathe out } \\
\text { completely } \\
\text { 10.Replace the } \\
\text { cover and if } \\
\text { needed, wait } \\
\text { for } 20-30 \mathrm{~s} \text { for } \\
\text { the second } \\
\text { application }\end{array}$ & $\begin{array}{l}\text { 1. Remove the } \\
\text { cap } \\
\text { 2. Open capsule } \\
\text { compartment } \\
\text { of the device } \\
\text { 3. Take out the } \\
\text { capsule from } \\
\text { folio and } \\
\text { place it in } \\
\text { compartment } \\
\text { in base of } \\
\text { inhaler } \\
\text { 4. Squeeze the } \\
\text { two buttons } \\
\text { inwards to } \\
\text { pierce the } \\
\text { capsule } \\
\text { 5. Keep your head } \\
\text { up } \\
\text { 6. Breathe out } \\
\text { 7. Put } \\
\text { mouthpiece } \\
\text { between your } \\
\text { lips } \\
\text { 8. Breathe in } \\
\text { deeply and } \\
\text { strongly } \\
\text { 9. Hold breath for } \\
\text { 10 s } \\
\text { 10. Replace the cap } \\
\text { of the device }\end{array}$ & $\begin{array}{l}\text { 1. Remove the } \\
\text { cap } \\
\text { 2. Open capsule } \\
\text { compartment } \\
\text { of the device } \\
\text { 3. Take out the } \\
\text { capsule from } \\
\text { folio and } \\
\text { place it in } \\
\text { compartment } \\
\text { in base of } \\
\text { inhaler } \\
\text { 4. Squeeze the } \\
\text { two buttons } \\
\text { inwards to } \\
\text { pierce the } \\
\text { capsule } \\
\text { 5. Keep your head } \\
\text { up } \\
\text { 6. Breathe out } \\
\text { 7. Put } \\
\text { mouthpiece } \\
\text { between your } \\
\text { lips } \\
\text { 8. Breathe in } \\
\text { deeply and } \\
\text { strongly } \\
\text { 9. Hold breath for } \\
10 \mathrm{~s} \\
\text { 10. Replace the cap } \\
\text { of the device }\end{array}$ & $\begin{array}{l}\text { 1. Remove the } \\
\text { cap } \\
\text { 2. Press on } \\
\text { the dose } \\
\text { adjustment } \\
\text { button at the } \\
\text { side until a click } \\
\text { is heard. } \\
\text { 3. Keep your head } \\
\text { up } \\
\text { 4. Breathe out } \\
\text { 5. Put } \\
\text { mouthpiece } \\
\text { between your } \\
\text { lips } \\
\text { 6. Breathe in } \\
\text { deeply and } \\
\text { strongly } \\
\text { 7. Take away } \\
\text { inhaler from } \\
\text { your mouth } \\
\text { without } \\
\text { breathing out } \\
\text { 8. Hold breath for } \\
\text { 10 s } \\
\text { 9. Breathe out } \\
\text { completely } \\
\text { 10. Replace the cap } \\
\text { of the device }\end{array}$ & $\begin{array}{l}\text { 1. Remove the cap } \\
\text { 2. Hold inhaler in } \\
\text { upright position } \\
\text { by grasping } \\
\text { with your } \\
\text { thumb and } \\
\text { index finger } \\
\text { 3. Before loading } \\
\text { a dose, shake } \\
\text { the device up } \\
\text { and down. Push } \\
\text { dose leading } \\
\text { compartment } \\
\text { downward once } \\
\text { until a click is } \\
\text { heard and leave } \\
\text { it. While leaving, } \\
\text { you must hear } \\
\text { another click } \\
\text { 4. Keep your head } \\
\text { up } \\
\text { 5. Breathe out } \\
\text { 6. Put mouthpiece } \\
\text { between your } \\
\text { lips } \\
\text { 7. Breathe in } \\
\text { deeply and } \\
\text { strongly } \\
\text { 8. Take away } \\
\text { inhaler from } \\
\text { your mouth } \\
\text { without } \\
\text { breathing out } \\
\text { 9. Hold breath for } \\
\text { 10 s } \\
\text { 10 Replace the } \\
\text { cap of the } \\
\text { device }\end{array}$ \\
\hline
\end{tabular}


Statistical Package for the Social Sciences (SPSS) for Windows, Version 16.0 (Released 2007; SPSS Inc., Chicago, IL, USA), was used. The relationship between skill scores and age and working time as a family physician was evaluated with Spearman's correlation test; the relationship between skill scores and gender, the previous education of a family physician on the usage of inhaler device, and physician's prescribing inhaler device to patient was evaluated with Student's t-test or Mann-Whitney $U$ test depending on the occurrence of normal distribution. A p value of $<0.05$ was accepted to be statistically significant.

\section{RESULTS}

Of the family physicians who participated in the study, 28 (56\%) were females and 22 (44\%) were males. The mean age was $36.3 \pm 6.7$ years, and the mean working time as a family physician was $5.12 \pm 2.8$ years. Nineteen (38\%) family physicians had participated in an education program on the usage of inhaler device. Of the family physicians, 22 (44\%) stated that they knew how to use inhaler devices, 25 (50\%) had some knowledge regarding their use, and $3(6 \%)$ had no knowledge. The distribution of the names of inhaler devices that they knew is presented in Figure 1. The most commonly known inhaler device by family physicians (43 physicians) was MDI followed by discus, handihaler, turbuhaler, aerolizer, and easyhaler. Sanohaler was not known by family physicians. Table 2 shows how 47 physicians learned to use the devices.

Twenty-nine of the physicians stated that they provided education on the usage of inhaler devices to their patients, but 21 physicians did not. One physician told that he only prescribed MDI to patients, thereby providing education on the use of MDI. The reasons for not providing education are summarized in Table 3. Most of the physicians stated that they did not provide education because they thought that it must have been provided by the physician who had prescribed the device for the first time. Moreover, specialists in chest diseases, family physicians, pharmacists, pharmacy technicians, and educated nurses were specified as the health staff who could provide education (Table 4).

It was revealed that the family physicians who provided education to their patients frequently asked them to use the inhaler devices that they carried with them and checked whether they used it correctly. When the patients used it incorrectly, physicians warned and corrected them. Only one physician stated that he had an MDI device for demonstration purposes and showed its usage to patients for whom he had prescribed that device. There was no other physician who had

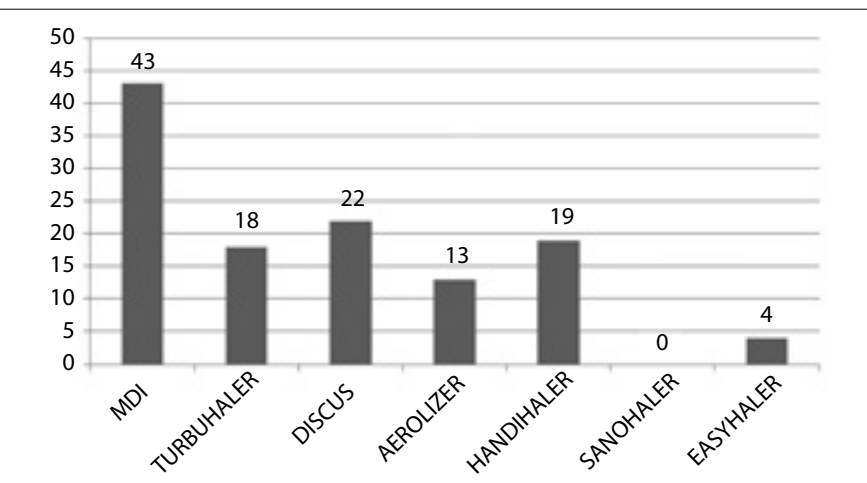

Figure 1. The distributions of the types of inhaler devices that were specified to be known by family physicians

*Participants told one or more device names

MDI: Metered-dose inhaler a brochure regarding inhaler devices or a demonstration device at the work place.

Six of the family physicians told that they knew all the steps in the use of seven different inhaler devices, but two did not know anything regard-

Table 2. The ways of learning how to use inhaler devices for family physicians

\begin{tabular}{|l|c|c|}
\hline Ways of learning & $\mathbf{n}$ & $\%$ \\
\hline $\begin{array}{l}\text { Educational programs of family medicine } \\
\text { By evaluating patients when they bring }\end{array}$ & 19 & 38 \\
\hline $\begin{array}{l}\text { Due to the presence of an inhaler device } \\
\text { user in the family }\end{array}$ & 7 & 11 \\
\hline $\begin{array}{l}\text { Experience } \\
\text { During the education in the faculty of medicine }\end{array}$ & 5 & 12 \\
\hline With the visits of medical representatives & 4 & 8 \\
\hline By examining drug brochures & 4 & 8 \\
\hline Because of using the device for their own disease & 1 & 2 \\
\hline *Participants stated more than one way of learning & & \\
\hline
\end{tabular}

Table 3. The reasons for not providing education on inhaler devices to patients by family physicians

\begin{tabular}{|l|c|c|}
\hline Reasons & $\mathbf{n}$ & $\%$ \\
\hline $\begin{array}{l}\text { Thinking that the physician who firstly prescribed } \\
\text { the device must have explained the usage }\end{array}$ & 13 & 61.9 \\
$\begin{array}{l}\text { Thinking that pharmacist and pharmacy technician } \\
\text { must have explained the usage }\end{array}$ & 3 & 14.2 \\
$\begin{array}{l}\text { Thinking that patient must have learned } \\
\text { from the brochure }\end{array}$ & 1 & 4.8 \\
$\begin{array}{l}\text { Limited time } \\
\text { Being afraid of giving incorrect education to patient }\end{array}$ & 1 & 4.8 \\
\hline $\begin{array}{l}\text { The absence of demonstration device for providing } \\
\text { education }\end{array}$ & 1 & 4.8 \\
\hline Total & 21 & 100 \\
\hline
\end{tabular}

Table 4. The suggestions of family physicians about the person who must provide education on inhaler device to patients

\begin{tabular}{|l|c|} 
Who should give the education to patient & $\mathbf{n}$ \\
on the usage of inhaler device? & 21 \\
\hline Specialist in chest diseases & 19 \\
Family physician & 17 \\
The physician who first prescribed the device & 6 \\
Pharmacist and pharmacy technician & 6 \\
Nurse & \\
Everybody who knows the devices & 5 \\
(another patient, patient's relative, etc.) & \\
*Some physicians gave more than one answer &
\end{tabular}


ing the devices. Of the six family physicians who knew how to use the devices, three learned regarding the usage during education on family medicine, two learned because of the presence of a family member who used an inhaler device, and one learned during internship because of interest in chest diseases. The mean skill scores for the usage of inhaler devices were $7.96 \pm 2.91$ for $\mathrm{MDI}, 7.54 \pm 3.93$ for discus, $7.28 \pm 4.04$ for handihaler, $6.38 \pm 4.4$ for aerolizer, $6.12 \pm 4.22$ for turbuhaler, $5.98 \pm 4$ for easyhaler, and $5.72 \pm 4.59$ for sanohaler, respectively. With regard to skill scores for the usage of inhaler device, no difference was found between males and females ( $p=0.477$ for $\mathrm{MDI}, p=0.259$ for turbuhaler, $p=0.877$ for discus, $p=0.511$ for aerolizer, $p=0.438$ for handihaler, $p=0.328$ for sanohaler, and $p=0.585$ for easyhaler). No correlation was detected between age and working time as a family physician and skill scores $(p=0.893$, $\mathrm{R}=-0.031 ; \mathrm{p}=0.525, \mathrm{R}=0.143$, respectively). The skill scores for MDI, turbuhaler, aerolizer, and handihaler devices was higher in physicians who had attended the session on education regarding inhaler devices than in physicians who did not attend any session on education $(p=0.049$, $p=0.05, p=0.013$, and $p=0.021$, respectively). The scores for the usage of MDI, turbuhaler, discus, aerolizer, handihaler, and easyhaler of physicians who did not explain the usage of inhaler devices to their patients were lower than physicians who explained the usage $(p=0.008, p=0.05$, $p=0.013, p=0.002, p<0.001$, and $p=0.002$, respectively). The skill scores were similar between the family physicians who agreed that "family physicians must provide education to their patients on inhaler devices" and those who disagreed $(p=0.049$ for MDI, $p=0.054$ for turbuhaler, $p=0.153$ for discus, $p=0.013$ for aerolizer, $p=0.021$ for handihaler, $p=0.949$ for sanohaler, and $p=0.522$ for easyhaler). The parameters affecting the scores for the usage of devices are summarized in Table 5.

\section{DISCUSSION}

On evaluating the approach of primary care physicians to the education on inhaler devices in our study, it was found that several physicians (42\%) did not provide education on the usage of these devices to their patients. Most did not feel the need to provide education because they thought that "the physician who had firstly prescribed the device or a pharmacist or pharmacy technician must have explained its usage." However, in our study, the scores for the usage of inhaler device were significantly lower in physicians who did not provide education on inhal- er devices to their patients than in physicians who provided education. It was observed that the family physicians with the highest skill scores for the devices, except MDI, the oldest and the most conventional inhaler device, and sanohaler, the last inhaler to be introduced in the market, explained their usage to their patients. This result can indicate that there is no problem regarding the knowledge and explanation of MDI, but there is not yet enough knowledge on sanohaler device. For obtaining efficiency similar to that associated with systemic treatment, fewer medications are used in inhalation treatment than those used in systemic treatment. This also decreases systemic side-effects. However, patient compliance and the correct use of inhalation devices are important for this treatment method to be effective. Considering the facts that only $15 \%-20 \%$ of the inhaler aerosol particles reach the lungs even under the best conditions and the amount of drug stored in the lungs can increase from $7.2 \%$ to $22.8 \%$ if appropriate techniques are used, it is clear that accurate usage of inhaler devices is very important (9). According to the studies conducted previously, few differences are seen among different inhaler devices with regard to efficiency if they are accurately used. However, many patients do not use inhaler devices correctly $(10,11)$. In the studies conducted in Turkey, the rate of correct usage of inhaler devices by patients was found to be quite low $(5,12)$. For preventing the errors made in the usage of all inhalation devices, all health staff should pay attention to the education on inhaler use as a part of treatment (13).

The results of the study also suggested that the family physicians who did not provide education avoided doing so because they did not have the knowledge regarding the usage of the inhaler devices. It is surely beyond doubt that the prescribing physician has the primary responsibility. However, other health workers also have a role in the evaluation of the correct usage of the inhaler device and in patient education (14). It is proved that education is not always given by an appropriate person. Device education involves a vast majority of health staff, including physicians, nurses, and pharmacists. Health workers should not oversimplify education thinking that the education must have already been given, and they should have adequate knowledge on inhaler techniques (15). The physicians participating in our study agreed that device techniques should be explained to patients by a specialist in chest diseases, family physician, pharmacist, pharmacy technician, nurse, and anyone who has

Table 5. Parameters for physicians and device usage skill scores

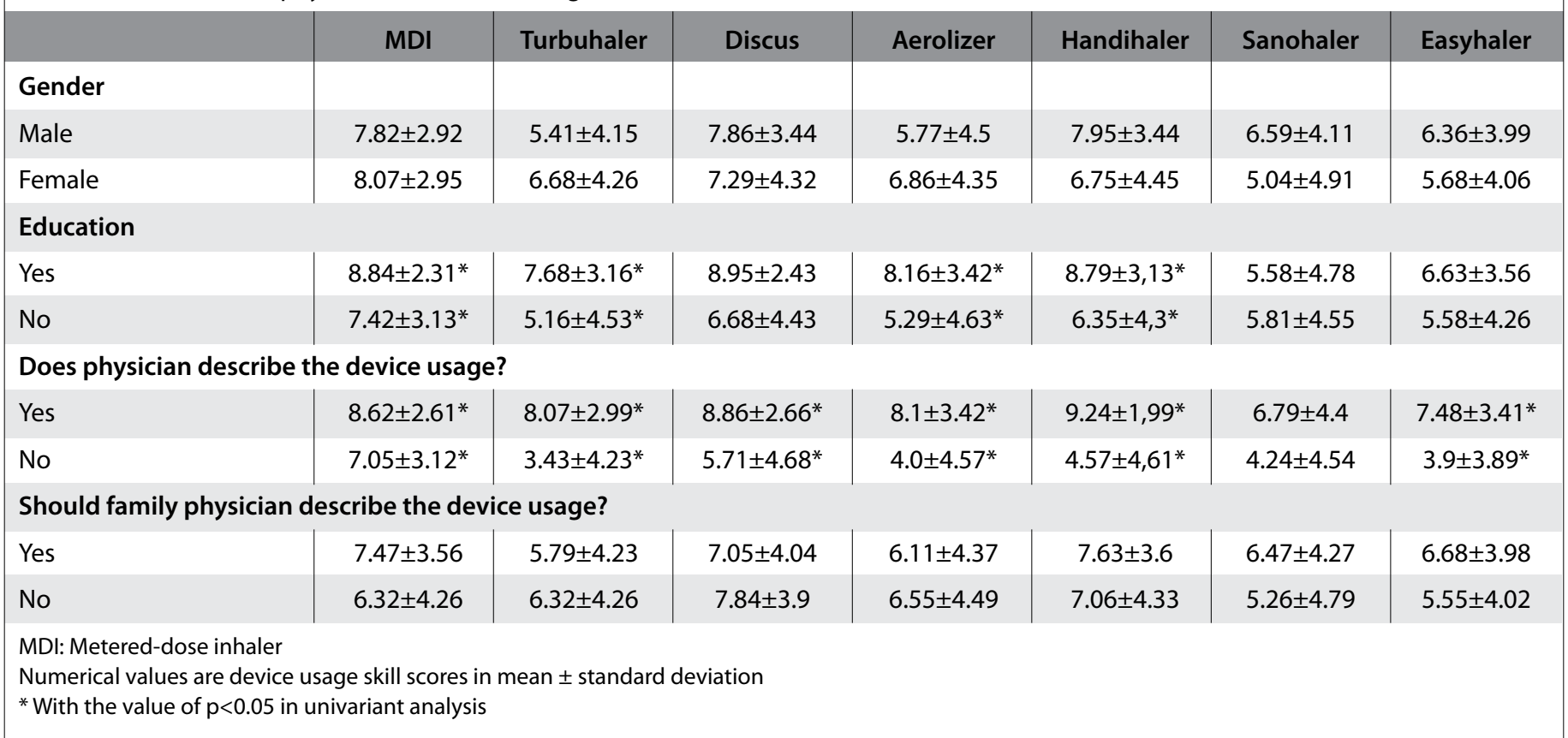


acquired education on the issue. Repetitive educations and directives are significantly correlated with the correct usage of inhaler devices, regardless of their type (11). One physician assumed that the patient had learned how to use the device from its brochure. Lenney et al. (16) compared patients learning the usage of MDI from the brochure and from a physician, and they found that the rates of correct usage were $21 \%$ in patients who learned from the brochure and $52 \%$ in patients who were educated by a physician. The family physicians providing education regarding the usage of inhaler devices stated that they mostly did this to check whether the patients with devices used them correctly. Except one physician, there was no family physician having a demonstration device and brochure at their work places. Only 19 physicians (38\%) told that they had attended a meeting in which education had been provided on inhaler devices, and that they had been educated via a slide show and by using demonstration devices in groups. Other physicians learned the usage of the devices by trying it with their patients or with a family member who used the device or by using it for treating their own diseases. The skill scores of physicians who received the education were significantly higher than physicians who did not. These results show the importance of education regarding the usage of the device. Of the 50 family physicians, only three stated that they did not know the devices. However, in the evaluation of the usage with demonstration devices, the rates of correct usage were quite low. In the study by Ünlü et al. (17), in which the knowledge of health workers on the usage of inhaler device was evaluated, they found the rates of correct usage as $76.8 \%$ for MDI, $50.8 \%$ for turbuhaler, and $44.5 \%$ for discus. The mean skill rate was 6.94 for MDI, 4.86 for turbuhaler, and 4.15 for discus. In our study, skill rates for MDI, discus, and turbuhaler were a little higher than those in this study. The device that was similarly applied in a more accurate manner was MDI. Plaza et al. (18) reported in their study that the knowledge of physicians on inhaler devices was insufficient and new educational programs were needed, particularly the practicing physicians should be targeted in education. In INTEDA-1, which is the most recent study that has been conducted on physicians and inhaler usage in our country, the views of a total of 684 physicians on inhaler usage were evaluated through the questionnaire technique. Most of the physicians participating in this study were specialists and residents working in the departments of chest diseases (37.5\%) and pediatrics (38.1\%), respectively. The rate of physicians working as family physicians and practicing physicians was $13.3 \%$. Only $18.5 \%$ of the participants specified that they had enough knowledge on inhaler usage. Of the physicians, 70\% provided education on inhaler usage themselves while prescribing the drug for the first time, and most of them provided education to the patient verbally. A total of $98 \%$ of physicians participating in the study mentioned that an extensive education on inhaler usage was needed for physicians and other health staff (19).

It is clear that the education should not be limited to only one session, and all health workers should be involved in regular educational programs. In our study, it was observed that physicians receiving education and physicians explaining the device to the patient were correlated. Most of our physicians stated that they were highly pleased with the visit; thus, they had an opportunity for reviewing the steps in the usage of the inhaler devices in which they were not efficient. Our study demonstrated that the education provided on the usage of inhaler devices created more awareness among health staff.

\section{CONCLUSION}

Primary care physicians have important responsibilities for the prevention of the incorrect usage of inhaler devices by patients. Our study revealed that family physicians had shortcomings regarding the usage of inhaler devices, and it was thought that in-service training regarding inhaler devices would lead to a significant increase in the awareness of this issue.
Ethics Committee Approval: Ethics committee approval was received for this study from the ethics committee of Düzce University Faculty of Medicine (Decision No: 2013/365)

Informed Consent: Informed consent was obtained from doctors who participated in this study.

\section{Peer-review: Externally peer-reviewed.}

Author Contributions: Concept - E.T., K.S., H.S., S.I.; Design - E.T.; Supervision K.S.; Resource - H.S.; Materials - A.N.A.; Data Collection and/or Processing - E.T., S.I; Analysis and/or Interpretation - K.S., H.S.; Literature Review - E.T.; Writer - E.T., A.N.A.; Critical Review - H.S., K.S.; Other - S.I.

Conflict of Interest: No conflict of interest was declared by the authors.

Financial Disclosure: The authors declared that this study has received no financial support.

\section{REFERENCES}

1. Virchow JC, Crompton GK, Dal Negra R, Pedersen S, Magnan A, Seidenberg J, et al. Importance of inhaler devices in the management of airway disease. Respir Med 2008; 102: 10-9. [CrossRef]

2. Chrystyn H. Do patients show the same level of adherence with all dry powder inhalers? Int J Clin Pract 2005; 59: 19-25. [CrossRef]

3. Giraud V, Roche N. Misuse of corticosteroid metered dose inhaler is associated with decreased asthma stability. Eur Respir J 2002; 19: 246-51. [CrossRef]

4. Van Der Palen J, Klein JJ, Kerkhoff AH, Van Herwaarden CL. Evaluation of the effectiveness of four different inhalers in patients with chronic obstructive pulmonary disease. Thorax 1995; 50: 1183-7. [CrossRef]

5. Mirici A, Meral M, Akgün M, Sağlam L, İnandı T. İnhalasyon tekniklerine hasta uyumunu etkileyen faktörler. Solunum Hastalıkları 2001; 12: 13-21.

6. Melani AS, Zanchetta D, Barbato N, Setsini P, Cinti C, Canessa PA, et al. Associazione Italiana Pneumologi Ospedalieri Educational Group. Inhalation technique and variables associated with misuse of conventional metered-dose inhalers and newer dry powder inhalers in experienced adults. Ann Allergy Asthma Immunol 2004; 93: 439-46. [CrossRef]

7. Hacıevliyagil SS, Arıkan ÖÖ, Günen H. Hastaların inhaler ilaçları kullanım becerileri. Hacettepe Üniversitesi Eczacılık Fakültesi Dergisi 2005; 25: 51-60.

8. Uzuner A. Aile Hekimliği Günlük Pratiğinde En Sık Karşılaşılan Solunum Yolu Hastalıkları: Solunum Yolunun Hangi Hastalıkları Ülkemiz Birinci Basamağı İçin Önemlidir? Turkiye Klinikleri J Fam Med-Special Topics 2010; 1: 6-12.

9. Erk M. İnhalasyon Teknikleri. Toraks Dergisi 2002; 3: 7-13.

10. Lavorini F, Levy ML, Dekhuijzen PN, Crompton GK, ADMIT Working Group. Inhaler choice and inhalation technique: key factors for asthma control. Prim Care Respir J 2009; 18: 241-2. [CrossRef]

11. Lavorini F, Magnan A, Dubus JC, Voshaar T, Corbetta L, Broeders M, et al. Effect of incorrect use of dry powder inhalers on management of patients with asthma and COPD. Respir Med 2008; 102: 593-604. [CrossRef]

12. Ceylan E, Akkoçlu A, Ergör G, Yıldız F, İtil O. Astımlı hastaların inhaler kullanımı ve cihaz tercihleri: Doğru uygulama için eğitimin rolü. Eurasian J Pulmonol 2008; 10: 40-7.

13. Melani AS. Inhalatory therapy training: a priority challange for the physician. Acta Biomed 2007; 78: 233-45.

14. Yılmaz A, Bayramgürler $B$, Akkaya E. Evaluation of the usage techniques of the inhalation devices and the effect of training nurses. Turkish Respiratory Journal 2001; 2: 16-9.

15. Capstick TG, Clifton IJ. Inhaler technique and training in people with chronic obstructive pulmonary disease and asthma. Expert Rev Respir Med 2012; 6: 91-103. [CrossRef]

16. Lenney J, Innes JA, Cromptom GK. Inappropriate inhaler use:Assessment of use and patient preference of seven inhalation devices. EDICl. Respir Med 2000; 94: 496-500. [CrossRef]

17. Ünlü $M$, Şahin Ü, Öztürk $M$, Akkaya A. Sağlık personeli ve eczacıların inhalasyon aletlerinin kullanımıyla ilgili bilgilerinin araştırılması. Solunum Hastalıkları 2001; 12: 8-12.

18. Plaza V, Sanchis J, Roura P, Molina J, Calle M, Quirce S, et al. Physician's knowledge of Inhaler devices and Inhalation techniques remain poor in Spain. J Aerosol Med Drug Deliv 2012; 25: 16-22. [CrossRef]

19. Çalışkaner AZ, Öztürk C, Ceylan E, Pekcan S, Yılmaz Ö, Öztürk S, et al. The knowledge and considerations of the physicians regarding the inhaler devices in asthma and COPD: the INTEDA-1 study. Tuberk Toraks 2013; 61: 183-92. [CrossRef] 